\title{
The Contradiction of Obesity Incidence Based on Sleep Duration in Adolescents
}

\author{
Dwi Yulia Maritasari $^{1 *}$; Satria Nandar Baharza ${ }^{2}$, Febria Listina ${ }^{3}$ \\ 1*), 2,3 Universitas Mitra Indonesia
}

\begin{tabular}{l} 
ARTICLE INFO \\
\hline Article history: \\
Received April 12, 2019 \\
Revised May 02, 2019 \\
Accepted May 08, 2019 \\
\hline
\end{tabular}

Keyword:

Obesitas

Remaja

Durasi Tidur

*) corresponding author

Jl. ZA. Pagar Alam No.7, Gedong Meneng, Kec. Rajabasa, Kota Bandar Lampung, Lampung 35144

Email: dwiyulia@umitra.ac.id

DOI:https://doi.org/10.30604/jika.v4i1.184

\begin{abstract}
A B S T R A C T
Obesity is an abnormal state of excess body fat where obesity that occurs in adolescence increases the risk of obesity as an adult and causes several health problems. This study aims to differ the proportion of obesity incidence based on sleep duration in high school adolescents in the Tanah Abang District, Central Jakarta. The study design was cross sectional, sampling using the simple random sampling method, and a total sample of 100 students. Data analysis included univariate and bivariate analysis with chisquare tests. The results showed that respondents categorized as obese based on Body Mass Index (BMI) were 37 (37\%) adolescents, and respondents categorized as obese was based on Body Fat Percent (PLT) of 32 (32\%) adolescents. There is a difference in the proportion of obesity incidence based on sleep duration in adolescents ( $p$ value $=0.003, O R=5.79$ ). Adolescents should improve their sleep patterns according to the recommended duration to prevent obesity, which is at least 7 hours a day.
\end{abstract}

This is an open access article under the CC-BY-SA license.

\section{INTRODUCTION}

Obesity in adolescents will significantly increase the risk of obesity in adulthood and is associated with increased pain and increased risk of death (Bibbins-Domingo, Coxson, Pletcher, Lightwood, \& Goldman, 2007). Increased prevalence of obesity does not only occur in developing countries, but also occurs in developing countries (Lobstein, Baur, \& Uauy, 2004). In
Indonesia, according to Basic Health Research data in 2010 the national prevalence of obesity in adolescents aged 1618 years was $1.4 \%$ and increased to $1.6 \%$ in 2013 (Health Research and Development Agency, 2013).

Sleep is one of the factors that play an important role in the growth, maturation, and health of children and adolescents that allows 
affecting the body's hormones associated with growth, maturation, and energy balance. Lack of sleep will cause changes in the levels of several body hormones such as leptin, ghrelin, insulin, cortisol, and growth hormone. Changes in these hormones that contribute to energy imbalances and lead to overweight / obesity (Chen, Beydoun, \& Wang, 2008).

Some studies have found that sleep duration contributes to the cause of obesity. The systematic review study conducted on 36 articles identified from the MEDLINE database (National Library of Medicine, Bethesda, MD) showed that there were 4 cross sectional studies that reported a significant relationship between sleep duration and obesity in adolescents (Patel \& $\mathrm{Hu}$, 2008). Research results conducted on adolescents in China reported that there was a significant relationship between sleep duration and the incidence of obesity in both men and women (Guo et al., 2013).

Research conducted on adolescents in Turkey states that decreasing sleep duration significantly increases the risk of obesity (Ozturk et al., 2009). Research conducted on adolescents in America reports that the prevalence of obesity decreases in adolescents who have sleep duration between 6-8 hours and the prevalence of obesity increases in adolescents who have shorter sleep duration ( $\leq 4$ hours / night) or longer $(\geq$ 10 hours / night) (Lowry et al., 2012). Similarly, the results of a cross sectional study conducted in South Korea reported that the prevalence of obesity increased in adolescents who reported sleeping $<5$ hours and decreased prevalence in adolescents who reported sleeping $\geq 8$ hours (Song, Park, Paik, \& Joung, 2010b).

DKI Jakarta is the province that has the highest obesity prevalence compared to other provinces in Indonesia, especially the prevalence of obesity in adolescents aged 1618 years. In 2010 the prevalence of obesity in adolescents aged 16-18 years in DKI Jakarta amounted to $2.7 \%$, increasing to $4.2 \%$ in
2013 and this figure was above the national prevalence (Health Research and Development Agency, 2013). The purpose of this study was to prove the difference in the proportion of obesity incidence based on sleep duration on adolescents in senior high school of Tanah Abang District, Central Jakarta

\section{METHOD}

This research was conducted with a quantitative approach using a cross sectional design. This research was conducted in 2 senior high school of Tanah Abang District, Central Jakarta. The sample in this study was students who attended senior high school in the Tanah Abang District, Central Jakarta, which met the inclusion and exclusion criteria. The inclusion criteria in this study were 10th and 11th grade students, both men and women. While the exclusion criteria in this study are students who are sick / not attending school during the study or who are unwilling to become research respondents, and students who have been made respondents during the preliminary study. The minimum number of samples in this study was 100 respondents, who were selected using the Simple Random Sampling method.

The data sources in this study were primary data, namely percent body fat (PLT) in students obtained from anthropometric measurements using cardio to scan, and Body Mass Index (BMI) from measurements of weight using scales and height using microtoise. The instrument used in this study was a questionnaire to obtain sleep duration data. This study was conducted a bivariate analysis using a statistical test in the form of a chi square test.

\section{RESULTS AND DISCUSSION}

Univariate analysis was carried out to describe the description of the dependent variable distribution, namely obesity based on Body Mass Index (BMI) and Body Fat 
Percent. While the independent variable between sleep duration.

Table 1

Frequency Distribution of Obesity Events based on Body Mass Index (BMI) and Body Fat Percent (BFP) and Sleep Duration

\begin{tabular}{|c|c|c|}
\hline Variable & Total & Percentage $(\%)$ \\
\hline \multicolumn{3}{|l|}{ Obesity based on IMT } \\
\hline Obesity (> 2 SD) & 37 & 37 \\
\hline Not obese $(\leq 2 \mathrm{SD})$ & 63 & 63 \\
\hline \multicolumn{3}{|l|}{ Obesity based on PLT } \\
\hline Obesity (> 30\%) & 32 & 32 \\
\hline Not obese $(\leq 30 \%)$ & 68 & 68 \\
\hline \multicolumn{3}{|l|}{ Sleep Duration } \\
\hline Less $(<7$ Jam $)$ & 70 & 70 \\
\hline Normal (7 - 8 Jam) & 28 & 28 \\
\hline More (> 8 Jam) & 2 & 2 \\
\hline Total & 100 & 100 \\
\hline
\end{tabular}

Based on table 1 it is known that respondents categorized as obese based on Body Mass Index (BMI) were $37(37 \%)$ adolescents, and respondents categorized as obese was based on Body Fat Percent (PLT) of 32 (32\%) adolescents. Respondents who had less sleep duration ( $<7$ hours / night) were $70(70 \%)$ adolescents, while respondents who had a normal sleep duration ( 7 - 8 hours) were 28 $(28 \%)$ teenagers, and respondents who had excessive sleep duration $>8$ hours / night as many as $2(2 \%)$ teenagers. But in this study the variable duration of sleep was carried out by combining categories into 2 categories, namely less ( $<7$ hours / night), and normal $(\geq$ 7 hours / night).

Table 2

The difference in the incidence of obesity based on sleep duration in adolescents

\begin{tabular}{|c|c|c|c|c|c|c|c|c|}
\hline \multirow{3}{*}{$\begin{array}{c}\text { Independent } \\
\text { Variable }\end{array}$} & \multicolumn{4}{|c|}{ Obesity Case } & \multirow{2}{*}{\multicolumn{2}{|c|}{ Total }} & \multirow{3}{*}{$\begin{array}{c}\text { OR } \\
(95 \% \mathrm{CI})\end{array}$} & \multirow[t]{3}{*}{ pvalue } \\
\hline & \multicolumn{2}{|c|}{ Obesity } & \multicolumn{2}{|c|}{ Do not obesity } & & & & \\
\hline & $\mathrm{n}$ & $\%$ & $\mathrm{n}$ & $\%$ & $\mathrm{n}$ & $\%$ & & \\
\hline \multicolumn{9}{|l|}{$\begin{array}{l}\text { Sleep duration } \\
\text { (Based on IMT) }\end{array}$} \\
\hline Less & 33 & $47,1 \%$ & 37 & $52,9 \%$ & 100 & $100 \%$ & $\mathbf{5 , 7 9}$ & $\mathbf{0 , 0 0 3}$ \\
\hline Normal & 4 & $13,3 \%$ & 26 & $86,7 \%$ & 100 & $100 \%$ & $(1,831-18,356)$ & \\
\hline \multicolumn{9}{|l|}{$\begin{array}{l}\text { Sleep duration } \\
\text { (Based on PLT) }\end{array}$} \\
\hline Less & 29 & $41,4 \%$ & 41 & $58,6 \%$ & 100 & $100 \%$ & 6,366 & 0,004 \\
\hline Normal & 3 & $10,0 \%$ & 27 & $90,0 \%$ & 100 & $100 \%$ & $(1,763-22,990)$ & \\
\hline
\end{tabular}

Table 2 shows that of $70(70 \%)$ adolescents who had less sleep duration, $33(47.1 \%)$ adolescents and 37 (52.9\%) adolescents were not obese based on the Body Mass Index (BMI). While from 30 (30\%) adolescents who had a normal sleep duration, as many as
$4(13.3 \%)$ adolescents were obese and 28 $(86.7 \%)$ adolescents were not obese based on Body Mass Index (BMI). The results of statistical tests obtained the value of value $=$ 0.003 , it can be concluded that there is a difference in the proportion of the incidence 
of obesity based on sleep duration in adolescents. From the results of the analysis obtained also the value of $\mathrm{OR}=5.79$ means that respondents who have less sleep duration have a chance of 5.79 times to be obese than respondents who have a normal sleep duration.

Based on the measurement of percent body fat (PLT), the results of statistical tests showed that as many as 29 respondents (41.4) who had slept duration were less obese. Whereas among respondents who have a normal duration there are 3 respondents (10.0) who are obese. The statistical test results obtained value value $=$ 0.004 , it can be concluded that there is a difference in the proportion of obesity incidence based on sleep duration in adolescents. From the results of the analysis obtained also the value of $\mathrm{OR}=6.366$ means that respondents who have less sleep duration have a chance of 6,366 times to be obese than respondents who have a normal sleep duration.

The results of this study indicate that the proportion of respondents who are obese occurs more frequently in respondents who have sleep duration $<7$ hours / day compared to respondents who have sleep duration $\geq 7$ hours / day. The results of this study are similar to studies carried out on adolescents in the Balearic Islands of Spain who stated that the proportion of adolescents who are obese is more in adolescents who have sleep duration $<7$ hours / day compared to adolescents who have sleep duration $\geq 7$ hours / day (Bibiloni et al., 2010). The results of a cross sectional study conducted in Korea also stated that the prevalence of obesity increased in adolescents who reported sleeping $<5$ hours and decreased prevalence in adolescents who reported sleeping $\geq 8$ hours / night (Song, Park, Paik, \& Joung, 2010a).

The results of this study also showed that there were differences in the proportion of obesity incidence based on sleep duration in adolescents, where adolescents who had slept duration $<7$ hours / day had a risk of 5.79 times to experience obesity compared to students who had slept duration $\geq 7$ hours / day. The results of this study are in line with research conducted based on data from the National Youth Risk Behavior Survey (YRBS) stating that there is a significant relationship between sleep duration and obesity in adolescents (Lowry et al., 2012). Similarly, research conducted on adolescents in Turkey also stated that a decrease in sleep duration was significantly associated with an increased risk of obesity (Ozturk et al., 2009).

The sleep process helps regulate hormone secretion and energy balance. Lack of sleep will cause changes in several body hormones such as leptin, green, insulin, cortisol, and growth hormone. These hormonal changes contribute to energy imbalances and trigger obesity (Chen et al., 2008). Lack of sleep will cause a decrease in leptin hormone and increase the hormone ghrelin, which will increase appetite, causing an increase in calorie intake which has an impact on increasing body weight (Patel \& Hu, 2008).

One study found that $40 \%$ of adolescents who have short sleep duration are reported to wake up tired (Knutson, 2005). Short sleep duration will also cause changes in metabolic hormones in increasing appetite, and have an effect on the selection of food types (Taheri, 2006). In addition, the results of other studies state that there is a significant relationship between the duration of sleep and TV viewing habits. Someone who has a short time to sleep is associated with increased TV viewing time, which ultimately has an impact on obesity (Kuriyan, Bhat, Thomas, Vaz, \& Kurpad, 2007).

\section{CONCLUSIONS AND RECOMMENDATION}

Based on the results of research conducted on adolescents in senior high school of Tanah Abang District, Central Jakarta, DKI Jakarta, it was found that $37 \%$ of adolescents were 
obese based on the index of body mass (BMI), and $32 \%$ of adolescents were obese based on percent body fat (PLT). There is a difference in the proportion of obesity events based on sleep duration ( $p$ value $=0.001$ )

Adolescents who have less or more sleep duration should better improve their sleep patterns by regulating the duration of sleep to normal, which is 7-8 hours a day to prevent obesity. In addition, teens should control their weight regularly by weighing at least once a month to monitor whether there is an increase or decrease in weight.

\section{REFERENCES}

Badan Penelitian dan Pengembangan Kesehatan. (2013). Riset Kesehatan Dasar (RISKESDAS) 2013. Badan Penelitian dan Pengembangan Kesehatan Kementerian Kesehatan RI Tahun 2013. Retrieve from: http://www.depkes.go.id/resources/do wnload/general/Hasil\%20Riskesdas\%2 02013.pdf

Bibbins-Domingo, K., Coxson, P., Pletcher, M. J., Lightwood, J., \& Goldman, L. (2007). Adolescent Overweight and Future Adult Coronary Heart Disease. New England Journal of Medicine. https://doi.org/10.1056/NEJMsa07316 $\underline{6}$

Bibiloni, M. D. M., Martinez, E., Llull, R., Juarez, M. D., Pons, A., \& Tur, J. A. (2010). Prevalence and risk factors for obesity in Balearic Islands adolescents. British Journal of Nutrition. https://doi.org/10.1017/S00071145099 9136X

Chen, X., Beydoun, M. A., \& Wang, Y. (2008). Is Sleep Duration Associated With Childhood Obesity? A Systematic Review and Meta-analysis. Obesity. https://doi.org/10.1038/oby.2007.63
Guo, X., Zheng, L., Li, Y., Zhang, X., Yu, S., Yang, H., ... Sun, Y. (2013). Prevalence and risk factors of being overweight or obese among children and adolescents in northeast China. Pediatric Research, 74(4), 443-449. Retrieved from https://www.nature.com/articles/pr201 $\underline{3116}$

Knutson, K. L. (2005). The association between pubertal status and sleep duration and quality among a nationally representative sample of US adolescents. American Journal of Human Biology, 17(4), 418-424. Retrieved from https://onlinelibrary.wiley.com/doi/abs /10.1002/ajhb.20405

Kuriyan, R., Bhat, S., Thomas, T., Vaz, M., \& Kurpad, A. V. (2007). Television viewing and sleep are associated with overweight among urban and semiurban South Indian children. Nutr J, 6(25), 1-4. Retrieved from https://nutritionj.biomedcentral.com/art icles/10.1186/1475-2891-6-25

Lobstein, T., Baur, L., \& Uauy, R. (2004). Obesity in children and young people: a crisis in public health. Obesity Reviews. https://doi.org/10.1111/j.1467789X.2004.00133.X

Lowry, R., Eaton, D. K., Foti, K., McKnightEily, L., Perry, G., \& Galuska, D. A. (2012). Association of Sleep Duration with Obesity among US High School Students. Journal of Obesity, vol. 2012, Article ID 476914, 9 pages, 2012.

\section{https://doi.org/10.1155/2012/476914}

Ozturk, A., Mazicioglu, M., Poyrazoglu, S., Cicek, B., Gunay, O., \& Kurtoglu, S. (2009). The relationship between sleep duration and obesity in Turkish children and adolescents. Acta Paediatrica, International Journal of Paediatrics, 98(4), 699-702 
Jurnal Aisyah: J urnal Ilmu Kesehatan, 4(1), J uni 2019, - 58

Dwi Yulia Maritasari; Satria Nandar Baharza; Febria Listina

https://doi.org/10.1111/j.16512227.2008.01169.x

Patel, S. R., \& Hu, F. B. (2008). Short sleep duration and weight gain: a systematic review. Obesity, 16(3), 643-653. Retrieved from https://onlinelibrary.wiley.com/doi/full /10.1038/oby.2007.118. https://doi.org/10.1038/oby.2007.118

Song, Y., Park, M. J., Paik, H. Y., \& Joung, H. (2010b). Secular trends in dietary patterns and obesity-related risk factors in Korean adolescents aged 10-19 years. International Journal of Obesity, 34(1), 48-56. https://doi.org/10.1038/ijo.2009.203

Taheri, S. (2006). The link between short sleep duration and obesity: we should recommend more sleep to prevent obesity. Archives of Disease in Childhood, 91(11), 881-884. Retrieved from

https://adc.bmj.com/content/91/11/881. $\underline{\text { short }}$ 